\title{
INFORMACJA PASAŻERSKA W LÓDZKIEJ KOMUNIKACJI MIEJSKIEJ WCZORAJ I DZIŚ
}

\author{
PASSENGER INFORMATION IN LÓDŹ PUBLIC TRANSPORT \\ YESTERDAY AND TODAY
}

\begin{abstract}
The article presents the impact of passenger information on transport decisions of residents and transport policy of cities. In addition, the author points out the place of passenger information in the concept of sustainable transport and the economy of sustainable development. Then, he describes the changes that took place in passenger information in Łódź. Among the elements of this system are: communication schemes, passenger information boards, voice announcements or mobile applications. Finally, the author presents the results of the MPK-Łódź survey on changes in passenger information in Łódź.
\end{abstract}

Keywords: passenger information, passenger information system, public transport, collective transport, passenger information boards, communication schemes, voice announcements, mobile applications

JEL Classification: $\mathrm{O} 18, \mathrm{O} 32, \mathrm{R} 41$

\section{Wstęp}

Nieodłącznym elementem ekonomii zrównoważonego rozwoju, zwłaszcza w zakresie miast i obszarów zurbanizowanych, jest koncepcja transportu zrównoważonego. Taki rodzaj transportu Organizacja Współpracy Gospodarczej i Rozwoju definiuje jako „transport, który nie zagraża ludzkiemu zdrowiu i ekosystemom

* doktorant, Uniwersytet Łódzki, Wydział Ekonomiczno-Socjologiczny, Katedra Ekonometrii Przestrzennej; tomasz.siedlecki@uni.lodz.pl 
oraz pozwala zaspokoić potrzeby transportowe poprzez zrównoważone wykorzystanie odnawialnych zasobów w ilości mniejszej niż wynosi ich stopa regeneracji oraz używanie nieodnawialnych zasobów w ilości niższej niż wynosi stopa rozwoju odnawialnych substytutów" "Większość funkcjonujących dziś wyjaśnień tego pojęcia sprowadza się do trzech podstawowych kategorii zagadnień: ekonomicznych, ekologicznych i społecznych. Istotną część tej koncepcji stanowi zrównoważony transport zbiorowy, któremu zwłaszcza w dużych ośrodkach miejskich stawiane są następujące cele:

- zakup i eksploatacja nowoczesnego, proekologicznego taboru,

- wydzielanie ulic, jezdni lub pasów ruchu dla pojazdów komunikacji miejskiej (m.in. w formie tzw. buspasów czy contra flow, tzn. pasów ruchu pod prą),

- priorytetyzacja transportu zbiorowego na skrzyżowaniach z sygnalizacją świetlną,

- rozwój systemów i infrastruktury transportu szynowego,

- koordynacja oraz synchronizacja rozkładów jazdy dla różnych rodzajów transportu,

- wdrażanie nowoczesnych rozwiązań w infrastrukturze transportu miejskiego (np. platform przystankowych dostosowanych do wysokości podłóg wozów, jak i systemów dynamicznej informacji pasażerskiej, tj. tablic telematycznych),

- tworzenie węzłów przesiadkowych ${ }^{2}$ (czyli zintegrowanych przystanków zaprojektowanych w sposób umożliwiający dogodną przesiadkę, zwłaszcza matkom z wózkami, osobom starszym i niepełnosprawnym),

- udostępnianie wyszukiwarek połączeń do efektywnego planowania podróży środkami komunikacji miejskiej,

- wprowadzanie integracji taryfowo-biletowej wraz z biletem w formie elektronicznej karty miejskiej, stanowiącej też coraz częściej unikalny identyfikator mieszkańca, nośnik jego podpisu elektronicznego i środek umożliwiający korzystanie z wielu usług publicznych w mieście ${ }^{3}$.

Przedmiotem analizy w niniejszym artykule będą przykładowe, także wyżej wymienione rozwiązania, jakie zastosowano w Lokalnym Transporcie Zbiorowym w Łodzi, mając za priorytet doskonalenie środków informacji pasażerskiej jako ważnego elementu koncepcji transportu zrównoważonego w miastach.

${ }^{1}$ OECD, Toward sustainable transportation, The Vancouver Conference 24-27 March, Vancouver 1996, s. 12.

2 A. Brzeziński, M. Rezwow, Zrównoważony transport - ekologiczne rozwiąania transportowe, http://www.transeko.pl/publik/Ekorozwoj_czesc\%20transportowa\%20A\%20Z.pdf, s. 10-11 [dostęp: 15.04.2018].

${ }^{3}$ M. Cichosz, Innowacje $w$ logistyce miejskiej - zrównoważony transport publiczny, „Prace Naukowe Uniwersytetu Ekonomicznego we Wrocławiu”, nr 383, Wydawnictwo Uniwersytetu Ekonomicznego we Wrocławiu, Wrocław 2015, s. 27. 
Za główny cel autor obrał sobie przedstawienie sposobu działania środków informacyjnych w publicznym transporcie zbiorowym w Lodzi - jakie funkcjonowały przed laty i jakie są wdrażane w chwili obecnej. Biorąc pod uwagę rosnące znaczenie marketingu oraz ciągły postęp technologiczny, które dostrzega się w wielu działach gospodarki, w tym także i w transporcie - co sprawia, że staje się on jeszcze bardziej zrównoważony - wysunięto tezę, że zmiany i unowocześnienia $\mathrm{w}$ informacji pasażerskiej komunikacji miejskiej w Łodzi wpływają dodatnio na zadowolenie pasażerów transportu publicznego z oferowanych usług przewozowych.

\section{Materiały i metodyka badań}

\subsection{Tablice czołowe na wiatach przystankowych w Lodzi}

Przystanki komunikacyjne są nie tylko podstawowymi obiektami infrastruktury transportu miejskiego, na których dokonuje się wymiana pasażerów, ale też jednym ze środków oferty przewozowej, realizującym postulat informacji, wygody oraz bezpieczeństwa. Wyposażenie przystanków powinno się składać: z rozkładów jazdy, ze schematów linii komunikacyjnych, taryf czy przepisów porządkowych. Niejednokrotnie pojawiają się na nich również wspomniane już nowoczesne systemy, które sygnalizują przyjazdy kolejnych pojazdów transportu zbiorowego ${ }^{4}$.

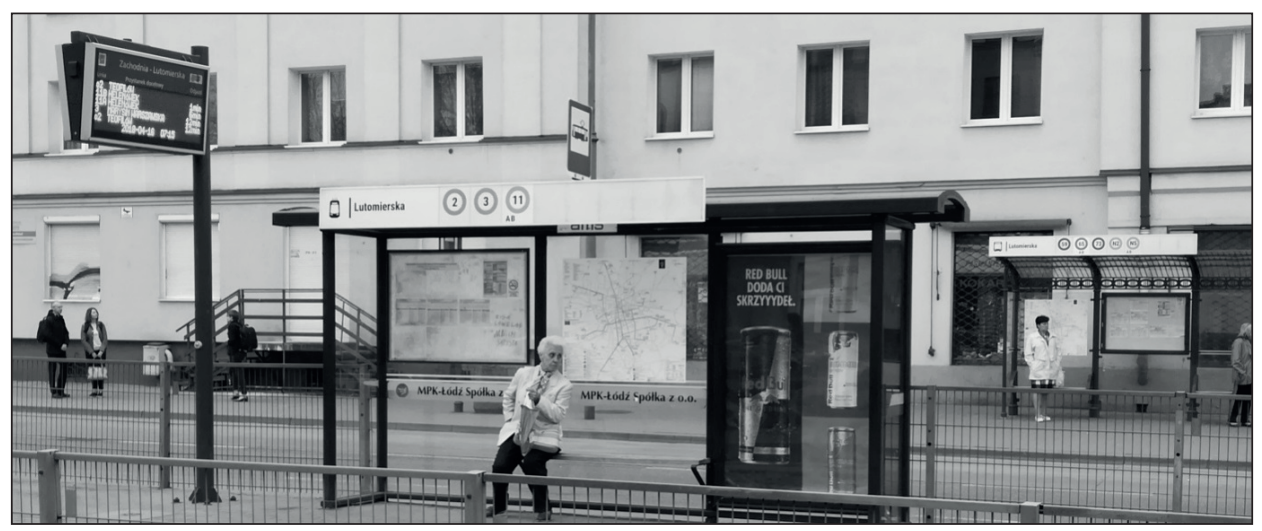

Rysunek 1. Tablice czołowe na wiatach przystankowych w Lodzi

Źródło: fot. ze zbiorów autora.

${ }^{4}$ Zarządzanie komunikacja miejska, red. O. Wyszomirski, Gdańska Fundacja Kształcenia Menedżerów, Gdańsk 1999, s. 25. 
Wraz z wdrożeniem nowego układu komunikacyjnego w Łodzi na początku kwietnia 2017 roku wprowadzono kilka nowości w zakresie informacji pasażerskiej. Jedna z nich dotyczyła montażu tablic czołowych na przystankach z wiatami. Na tablicach tych znalazło się miejsce na:

- symbol graficzny - znak w postaci tramwaju lub autobusu, który należy utożsamiać z rodzajem danego punktu postojowego,

- drugi człon nazwy przystanku - pierwszy człon stanowi nazwa ulicy lub alei, przy której usytuowany jest przystanek (nie widnieje on jednak na tablicy czołowej), drugi zaś człon najczęściej przyjmuje nazwę (przy zachowaniu poniższej kolejności):

- obiektu kolejowego (dworca, stacji, przystanku lub terminalu), lotniska,

- obiektu sportowego o randze ponadwojewódzkiej,

- ulicy/alei poprzecznej (zwykle tej, która znajduje się najbliżej przystanku),

- punktu węzłowego (np. ronda, placu),

- uczelni wyższej, placówki medycznej, placówki naukowo-technologicznej,

- cmentarza (pochodzi od nazwy osiedla bądź ulicy, przy której jest położony),

- obiektów znajdujących się w bezpośrednim otoczeniu przystanku: urzędów, muzeów, teatrów, ogrodów działkowych, zajezdni, targowisk,

- osiedla administracyjnego, jednostki morfogenetycznej miasta, obszaru SIM lub strefy przemysłowej,

- obiektów komercyjnych, tj. centrów handlowych, hoteli itp. (gdy ich nazwy są charakterystyczne, powszechnie rozpoznawalne, funkcjonują w świadomości mieszkańców lub wpisały się w historię miasta),

- numer najbliższej posesji lub bloku,

- numery linii komunikacyjnych (w okręgach kolorowych dla linii tramwajowych, ciemnoszarych dla dziennych linii autobusowych i jasnoszarych dla nocnych linii autobusowych), zatrzymujących się w obrębie tego samego przystanku.

Zastosowanie wyżej opisanego rozwiązania w łódzkiej komunikacji miejskiej ma przede wszystkim na celu umożliwienie podróżnym odczytu z dalszej odległości nazwy przystanku i linii, w które można przesiąść się na konkretnym przystanku.

\subsection{Nowa szata graficzna rozkładów jazdy na przystankach w Lodzi}

Najważniejszym elementem informacyjnym na przystankach komunikacyjnych jest rozkład jazdy. Stanowi on usystematyzowany według dni tygodnia wykaz godzin odjazdów środków transportu publicznego z wszystkich przystanków dla każdego wariantu linii wraz z zestawem czasów przejazdów, które są zróżnicowane 
w określonych porach doby. Poszczególne kursy przypisane są zwykle różnym rodzajom pojazdów (np. nisko- bądź wysokopodłogowym), jakimi dysponują operator publicznego transportu zbiorowego lub współpracujący z nim przewoźnicy ${ }^{5}$.

Zmiany w informacji pasażerskiej w Łodzi objęły także rozkłady jazdy. Przez wiele lat, aż do kwietnia ubiegłego roku, MPK-Łódź Sp. z o.o. wywieszało na przystankach czarno-białe rozkłady papierowe. Jedynym innym kolorem, którego używano na oznaczenie kursów obsługiwanych taborem niskopodłogowym, był kolor różowy. $\mathrm{Na}$ wcześniejszych wizualizacjach, poza trasą, najbardziej charakterystyczne i zarazem najobszerniejsze elementy rozkładu określonej linii komunikacyjnej stanowiły dwie tabele.

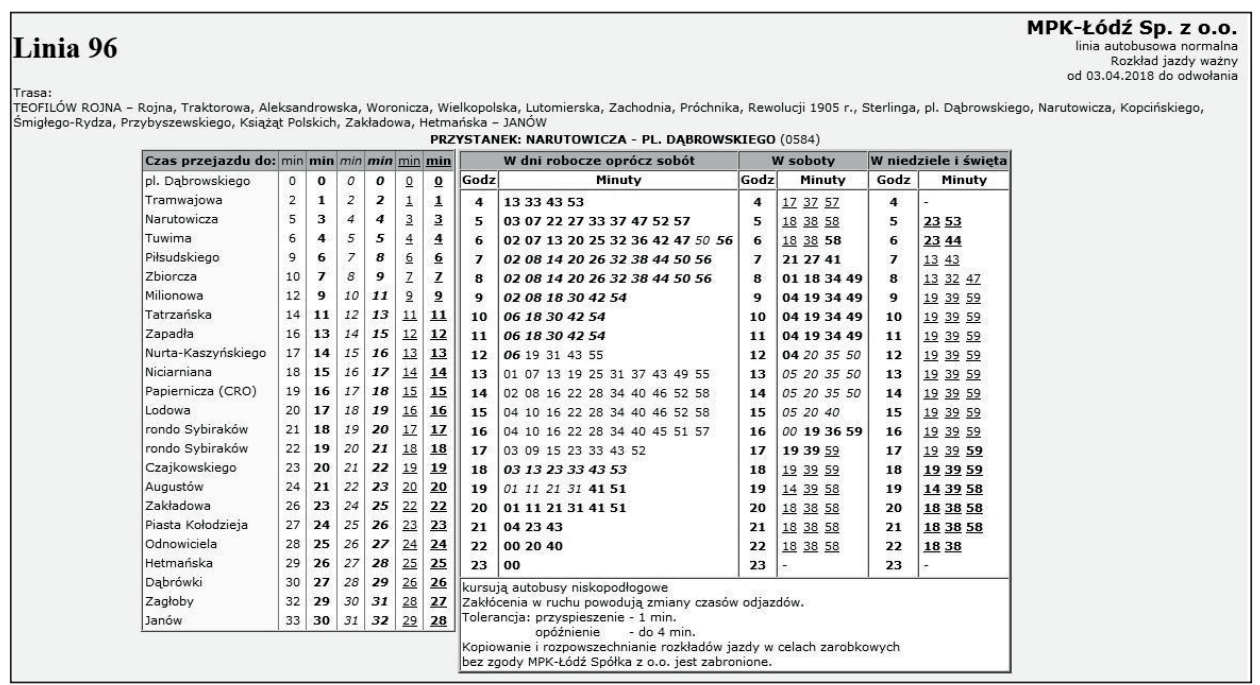

Rysunek 2. Stara szata graficzna rozkładów jazdy na przystankach w Lodzi

Źródło: Materiały Miejskiego Przedsiębiorstwa Komunikacyjnego-Łódź Sp. z o.o.

Pierwsza z nich zawierała wykaz kolejnych przystanków (jeden pod drugim) danej linii oraz czasy przejazdów do wymienionych punktów postojowych (wyróżnione pogrubieniami, podkreśleniami, kursywą). Z racji zróżnicowanych czasów pokonania pozostałej trasy o określonych porach doby niektóre rozkłady jazdy zawierały aż do 8 kolumn z różnymi czasami, co niejednokrotnie prowadziło do dezorientacji pasażerów. Inną wadą pierwszej z tabel była czcionka stosowana do zapisu nazw przystanków. Im więcej postojów było zaplanowanych do tzw. krańcówki, tym wielkość druku była coraz mniejsza, tak aby zmieścić w tabeli pełną listę pozostałych przystanków. 
Druga tabela prezentowała z podziałem na poszczególne godziny doby, a także z uwzględnieniem dni roboczych, sobót oraz niedziel i świąt, godziny kursów danego połączenia komunikacyjnego. Znajdujące się przy nich indeksy literowe oznaczały przykładowo wariant linii czy kursy zjazdowe do zajezdni.

Od 2 kwietnia 2017 roku zaczęła obowiązywać nowa szata graficzna łódzkich rozkładów jazdy. W międzyczasie Zarząd Dróg i Transportu w Łodzi w porozumieniu z Miejską Radą Seniorów w Łodzi wypracował drobne korekty tej wizualizacji, których celem była jeszcze większa czytelność i zrozumiałość rozkładów, szczególnie dla ludzi starszych.

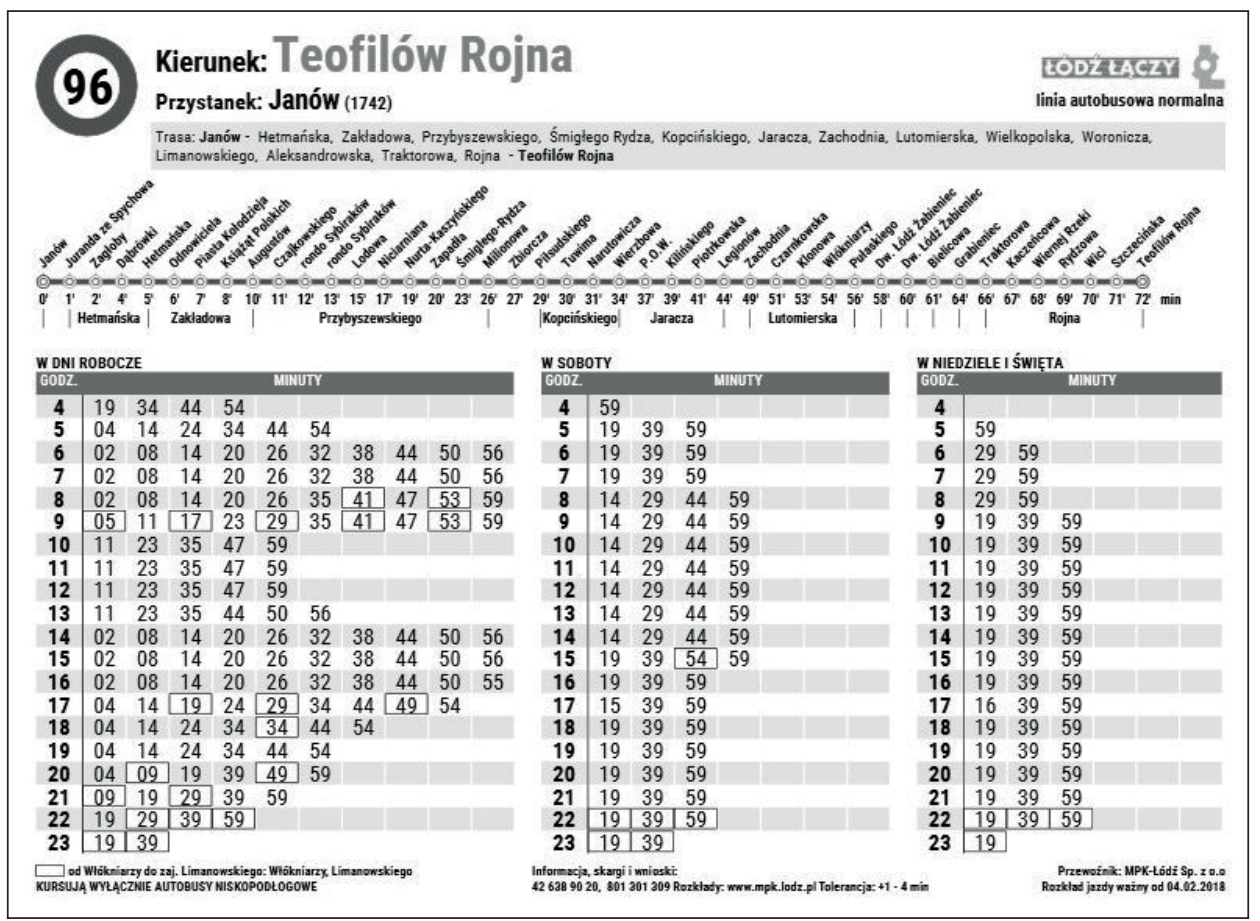

Rysunek 3. Nowa szata graficzna rozkładów jazdy na przystankach w Lodzi

Źródło: Materiały Zarządu Dróg i Transportu w Łodzi.

W stosunku do wersji z lat ubiegłych zmienił się przede wszystkim układ poszczególnych elementów rozkładu. Opisaną wcześniej pierwszą tabelę z następnymi przystankami i czasami przejazdów zastąpiono tzw. choinką, która niezmiennie uwzględnia pozostałe do końca trasy danej linii postoje oraz tylko jeden, maksymalny czas dojazdu do określonych przystanków. Odchodzące od niej gałęzie przedstawiają trasy linii wariantowych.

Autorzy zmian zastosowali również $\mathrm{w}$ projekcie nieużywaną dotychczas paletę barw. W wypadku połączeń tramwajowych obecnie numer linii jest 
umieszczony w okręgu, którego kolor odzwierciedla jeden z ciągów komunikacyjnych bądź linie podmiejskie, natomiast w odniesieniu do wszystkich połączeń autobusowych okręgi te mają nadany kolor szary. Zawarte pod okręgiem ewentualne indeksy literowe świadczą o wariantowości danej linii. Inne odcienie szarości zarezerwowano z kolei do wyróżnienia sąsiednich wierszy w powiększonej na niemal całą długość papierowego rozkładu tabeli z godzinami odjazdów. Dzięki takiemu poszerzeniu tabeli zwiększyła się także jej czcionka, co sprawiło, że godziny kursów są teraz bardziej widoczne dla wszystkich podróżnych. Ponadto w obecnie obowiązującej szacie graficznej rozkładów jazdy widnieją: wciąż bardziej wyszczególniony kierunek podróży, nazwa przystanku, rodzaj linii, data początkowa obowiązywania rozkładu, logotyp „Łódź łączy” oraz legenda wyjaśniająca wszelkie użyte w rozkładzie znaki.

\subsection{Nowe graficzne schematy komunikacyjne na przystankach w Lodzi}

Kolejną niezwykle istotną nowością w informacji pasażerskiej umieszczoną na przystankach tramwajowych i autobusowych w Łodzi okazały się schematy graficzne, prezentujące nowy układ komunikacyjny w mieście i zawierające przydatne wiadomości nie tylko dla samych mieszkańców, ale też dla turystów. Wcześniej pasażerowie mogli korzystać jedynie z typowo schematycznych wizualizacji systemu, które były dostępne na stronie internetowej MPK-Łódź Sp. z o.o. lub w pojazdach komunikacji miejskiej. Szczególnie chaotyczny i nieczytelny wydawał się schemat dziennych linii autobusowych, który w znikomym stopniu umożliwiał łodzianom dokładne zaplanowanie podróży wraz z wytypowaniem miejsc na mapie do ewentualnych przesiadek.

Nowe wizualizacje udostępnione mieszkańcom Łodzi od kwietnia 2017 roku składały się pierwotnie z dwóch części - typowego schematu linii tramwajowych jako głównego trzonu publicznego transportu zbiorowego w mieście (z naniesionymi symbolicznie liniami autobusowymi) oraz oddzielnego schematu linii autobusowych na bazie mapy Łodzi. Na pierwszym ze schematów szczególną uwagę podróżnych miał przykuwać szkielet połączeń tramwajowych. Zostały na nim uwypuklone m.in. tramwajowe ciągi komunikacyjne, których odzwierciedlenie można było również znaleźć na rozkładach jazdy w kolorowych okręgach, zawierających numery poszczególnych linii. Wszystkie przedstawione ciągi oznaczono następującymi kolorami:

- żółtym - dla Łódzkiego Tramwaju Regionalnego (ŁTR),

- niebieskim - dla Trasy Wschód-Zachód (WZ),

- jasnozielonym - dla Nowego Centrum Łodzi,

- różowym - dla al. Politechniki,

- fioletowym - dla ul. Kilińskiego, 
- ciemnozielonym - dla linii podmiejskich (do Pabianic, Konstantynowa Łódzkiego, Lutomierska, Zgierza i Ozorkowa),

- szarym - dla wszystkich linii autobusowych.

$\mathrm{Na}$ tramwajowych ciągach komunikacyjnych i trasach autobusowych zaznaczono krańcówki, przystanki dwu- i jednokierunkowe oraz przedstawiono rozmieszczenie przystanków na poszczególnych skrzyżowaniach czy węzłach. Poza tym z użyciem właściwych symboli graficznych umiejscowiono na schemacie: stacje kolejowe, dworce autobusowe, szpitale, targowiska i centra handlowe. Tego typu wizualizacje zostały przyklejone w formie dużych naklejek na wiatach ponad 920 przystanków tramwajowych i autobusowych na obszarze całej Łodzi.

Drugi ze schematów, przygotowany na bazie mapy miasta i pokazujący układ tras wszystkich linii autobusowych, został zamieszczony w Internecie (podobnie jak pierwszy) na stronach internetowych MPK-Łódź Sp. z o.o. oraz Zarządu Dróg i Transportu w Łodzi. Każdemu z połączeń autobusowych przyporządkowano inny kolor, którym oznaczono jego przebieg (w postaci linii) i krańcówki (w kształcie przyjętych jednolicie okręgów, pod którymi widniały ewentualne indeksy literowe, odzwierciedlające warianty danej linii). Ponadto na mapie, poza wymienionymi przy pierwszym schemacie obiektami, ulokowano symbole graficzne: państwowych uczelni wyższych, centrum przesiadkowego, Manufaktury, lotniska, Atlas Areny, stadionów piłkarskich, siedzib Urzędu Miasta Łodzi i Centrum Obsługi Mieszkańca. Mapa zawierała też zaznaczone inne ulice i sieć kolejową w mieście, obszary parków miejskich i zbiorników wodnych czy najwyższy punkt Łodzi. Tak pierwszy, jak i drugi schemat był dołączany do materiałów informacyjnych na temat zmian w układzie komunikacyjnym Łodzi, jakie rozdawano mieszkańcom w najbardziej strategicznych punktach miasta bądź wrzucano do skrzynek pocztowych na wielu łódzkich osiedlach.

To jednak nie koniec prac, jakie przez cały czas toczyły się nad graficznymi schematami komunikacyjnymi. Przy okazji wprowadzenia korekt do wspomnianego układu tras, które weszły w życie 4 lutego 2018 roku, Zarząd Dróg i Transportu w Łodzi zaprezentował nowe, udoskonalone schematy. Główna wizualizacja tras została oparta w całości na mapie Łodzi. Tym razem oprócz przebiegów linii autobusowych znalazły się w niej również wytyczone trasy linii tramwajowych, których kształt na mapie odzwierciedla stan faktyczny. Na schemacie zachowano przyjętą przed rokiem kolorystykę tramwajowych ciągów komunikacyjnych oraz kolor szary dla linii autobusowych, aczkolwiek mapa została też wzbogacona o trasy długookresowych linii zastępczych (kolor granatowy) oraz linii autobusowych z innych miast aglomeracji łódzkiej, których przebieg zilustrowano częściowo w kolorze szarym (na odcinkach, gdzie obowiązuje łódzka taryfa biletowa) i kolorze beżowym (na odcinkach, gdzie ważna jest taryfa biletowa poszczególnych miejscowości). 


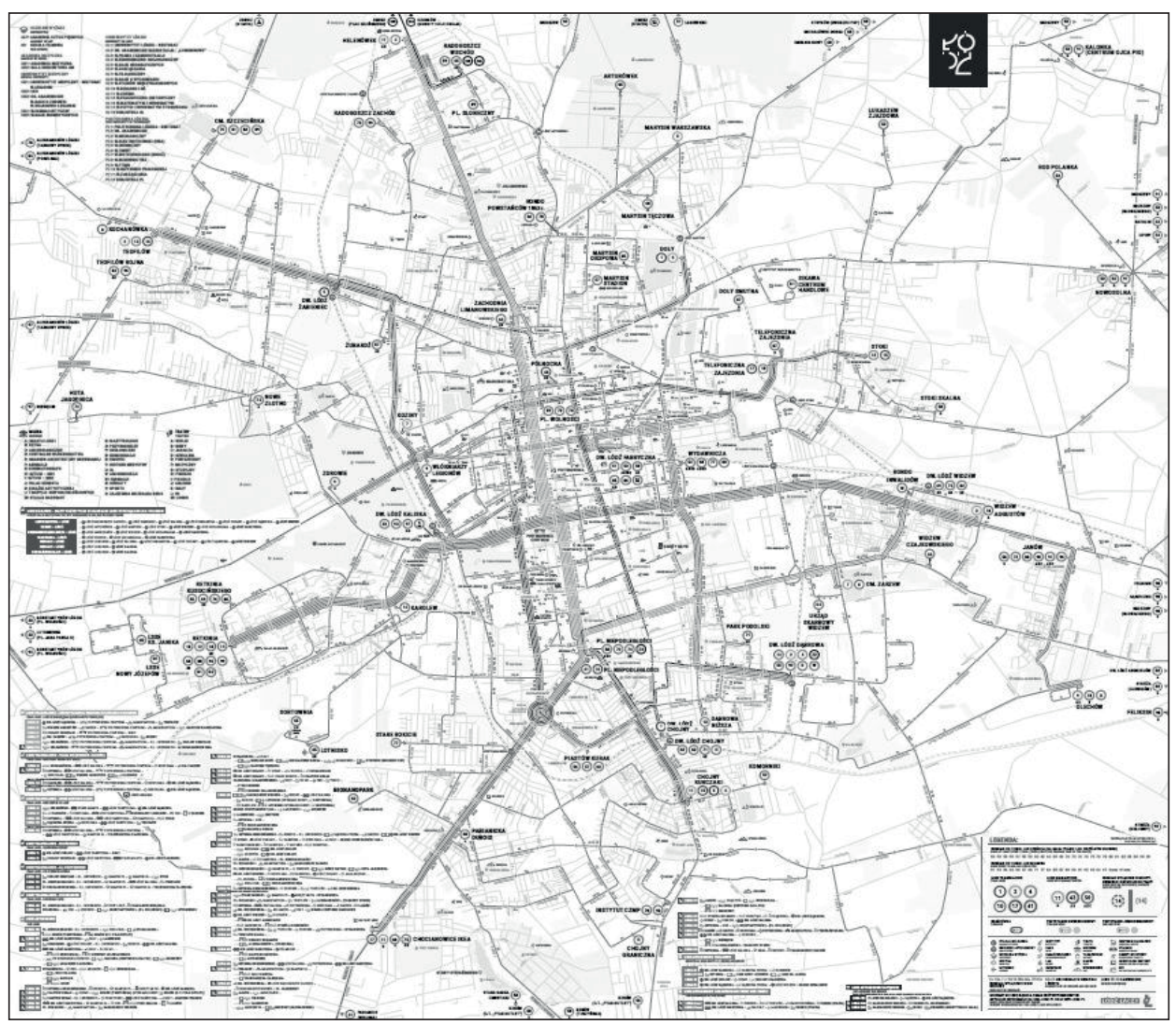

Rysunek 4. Nowy graficzny schemat komunikacyjny na przystankach w Lodzi

Źródło: Materiały Zarządu Dróg i Transportu w Łodzi.

Na samej nowej mapie, poza krańcówkami oraz przystankami dwu- i jednokierunkowymi, uwzględniono dodatkowo lokalizacje: stacji kolejowych, dworców autobusowych, wydziałów uczelni wyższych, szpitali, lotniska, instytutów, parków, pasaży/woonerfów, lasów, cmentarzy, teatrów, muzeów, targowisk, basenów, wzniesień, centrów handlowych, stadionów, obiektów sportowych, Łódzkiego Domu Kultury, Centrum Nauki i Techniki EC1 czy miejsc, gdzie następuje zmiana strefy biletowej. Jeszcze innym nowym elementem udoskonalonego schematu komunikacyjnego jest wykaz wszystkich linii tramwajowych, autobusowych, zastępczych i kolejowych (z biletami ważnymi tylko w granicach Łodzi w pociągach ŁKA i Polregio), w którym każde z wymienionych połączeń zawiera obie krańcówki oraz najistotniejsze punkty ( $\mathrm{w}$ tym przesiadkowe) na trasie wraz $\mathrm{z}$ odpowiednimi dla nich symbolami graficznymi. Tego typu mapy od kwietnia 2018 roku zawisły na ponad 620 przystankach tramwajowych i autobusowych, zastępując starszą wersję schematów, którą rozwieszano w tych miejscach rok wcześniej. 
Podczas zmian tras linii na początku lutego 2018 roku Zarząd Dróg i Transportu w Łodzi dokonał również prezentacji nowego schematu nocnych linii autobusowych i jednej tramwajowej. Grafika ta spełnia wszystkie standardy, jakie zostały zastosowane w jej dziennym odpowiedniku. Zrezygnowano jedynie z oznaczenia poszczególnych wydziałów uczelni wyższych na rzecz umiejscowienia miasteczek akademickich, w których studenci prowadzą aktywny tryb życia do późnych godzin nocnych. Od razu widoczną różnicą względem schematu dziennego jest z pewnością samo tło wizualizacji, w którego ramach projektanci przyjęli ciemnoszarą kolorystykę w celu oddania barw nocy.

Opisując różne rodzaje nowych schematów komunikacyjnych w łódzkiej komunikacji miejskiej, nie należy zapominać o kilku innych grupach mapek, jakie powstały w ostatnich miesiącach lub wciąż są tworzone z zamiarem udoskonalenia informacji pasażerskiej dla mieszkańców bądź turystów przebywających w Łodzi. Pośród nich są:

- schematy węzłowe - przedstawiają rozmieszczenie przystanków na kluczowych węzłach przesiadkowych w mieście; $\mathrm{w}$ grupie wybranych lokalizacji znalazły się: dworce - Łódź Fabryczna, Łódź Kaliska, Łódź Widzew, Łódź Żabieniec, Instytut Centrum Zdrowia Matki Polki, Centrum Kliniczno-Dydaktyczne, cmentarz Zarzew, Piotrkowska Centrum, plac Niepodległości, węzeł Doły, Manufaktura oraz kampusy Uniwersytetu Łódzkiego i Politechniki Łódzkiej (docelowo takie schematy będą dostępne w Internecie na wskazanej dalej podstronie Urzędu Miasta Łodzi),

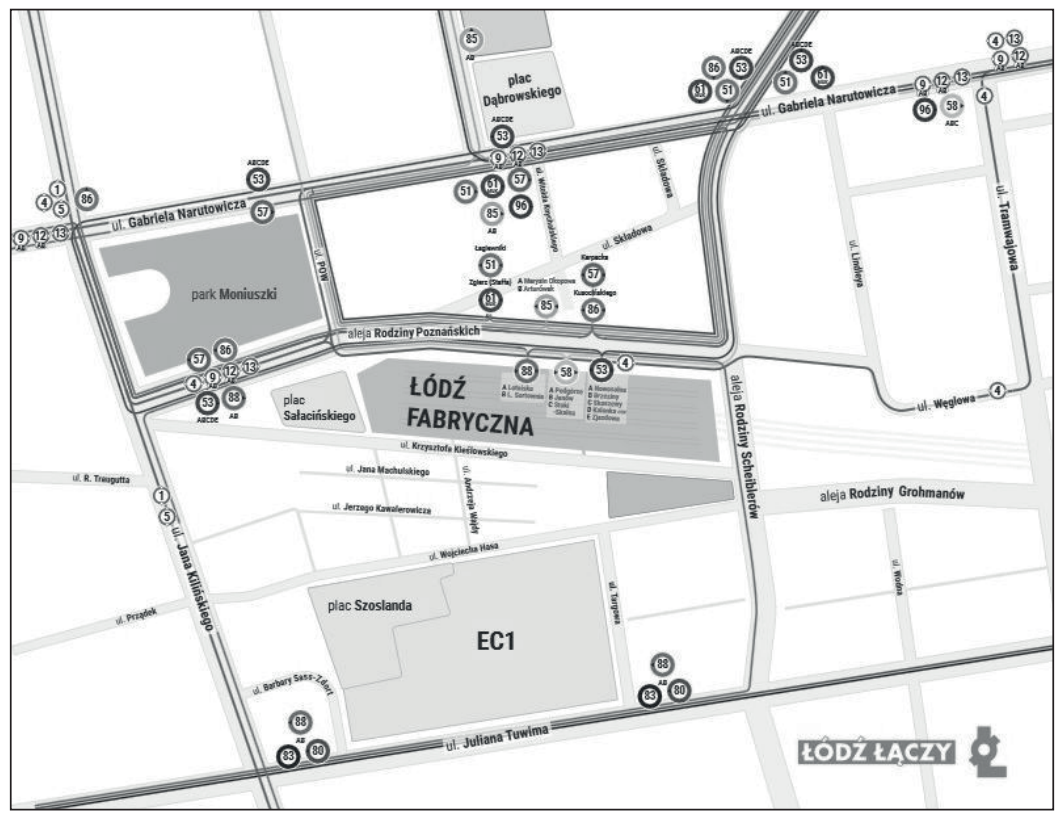

Rysunek 5. Graficzny schemat węzlowy dla dworca Lódź Fabryczna w Lodzi

Źródło: Materiały Zarządu Dróg i Transportu w Łodzi. 
- schematy indywidualne - mapy te uzupełniają schemat siatki połączeń oraz pozwalają na łatwiejszą orientację i dojazd w konkretne miejsca; jak na razie powstał zestaw schematów indywidualnych dla wszystkich linii autobusowych w mieście, a na przykładowej wizualizacji podane są: numer linii $\mathrm{w}$ okręgu o przydzielonym kolorze i z ewentualnymi indeksami literowymi wariantów linii podokręgiem, kompletna trasa (lub trasy wariantowe) danej linii w obu kierunkach, jej graficzny przebieg na mapie Łodzi, a także zaznaczone są wszystkie przystanki $\mathrm{w}$ ramach określonego połączenia wraz z ich nazwami, liniami, w które można przesiąść się w pobliżu, czy symbolami graficznymi ważnych obiektów i instytucji znajdujących się w bliskim sąsiedztwie przystanków,

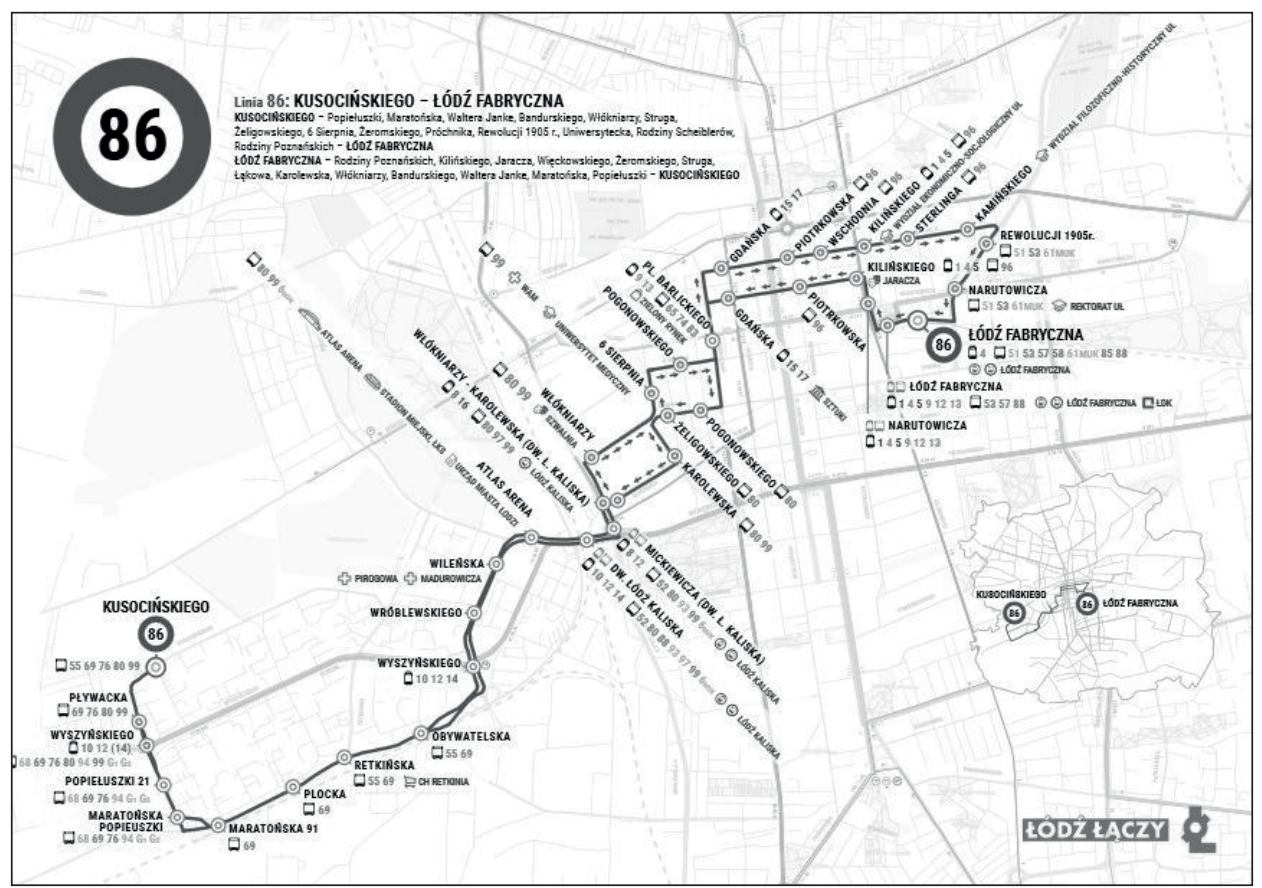

Rysunek 6. Graficzny schemat indywidualny dla przykładowej linii autobusowej w Lodzi

Źródło: Materiały Zarządu Dróg i Transportu w Łodzi.

- schematy z czasowymi zmianami w trasach komunikacji miejskiej - odzwierciedlają zmodyfikowany układ komunikacyjny wybranych fragmentów obszaru miasta, na których prowadzone są krótko- bądź długookresowe prace, np. remonty lub przebudowy, uniemożliwiające przejazd pojazdów łódzkiego transportu publicznego po stałych trasach. 


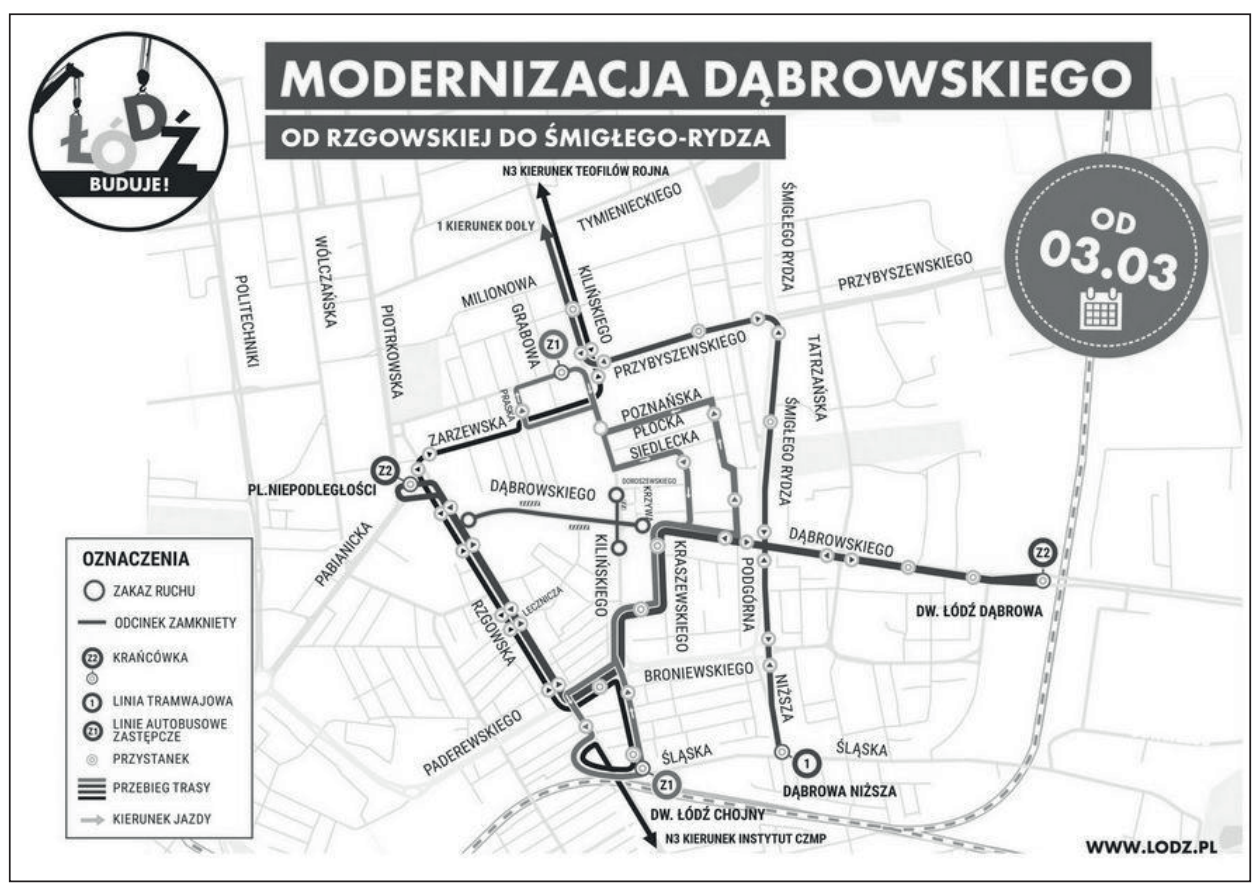

Rysunek 7. Graficzny schemat z czasowymi zmianami w trasach komunikacji miejskiej w Lodzi

Źródło: Materiały Zarządu Dróg i Transportu w Łodzi.

Wszystkie wizualizacje wymienionych rodzajów schematów komunikacyjnych można znaleźć na stronie internetowej Urzędu Miasta Łodzi w części „Transport i komunikacja” w zakładce „Pasażer” na podstronie „Schematy linii tramwajowych i autobusowych".

\subsection{Tablice informacji pasażerskiej na przystankach $w$ Lodzi}

Coraz powszechniej na obszarach miejskich sięga się dzisiaj po środki wykorzystujące systemy telematyczne, czyli „rozwiązania telekomunikacyjne, informatyczne i informacyjne oraz rozwiązania automatycznego sterowania dostosowane do potrzeb obsługiwanych systemów fizycznych - wynikających z ich zadań, infrastruktury, organizacji, procesów utrzymania oraz zarządzania - i zintegrowane z tymi systemami" ${ }^{6}$. Głównym celem stosowania telematyki w logistyce miejskiej jest optymalizacja dostępu do węzłów logistycznych, a także do infrastruktury

${ }^{6}$ K.B. Wydro, Telematyka - znaczenia i definicje terminu, „Telekomunikacja i Techniki Informacyjne" 2005, nr 1-2, s. 117. 
liniowej w miastach ${ }^{7}$. W zakresie komunikacji miejskiej standardowymi urządzeniami telematycznymi są tablice informacji pasażerskiej, składające się na całe systemy informacji pasażerskiej, które nadają komunikaty pomagające w planowaniu oraz korygowaniu procesów przemieszczania, dzięki czemu zwiększa się wydajność przewozów, poprawia się bezpieczeństwo, a zmniejsza niekorzystne oddziaływanie na środowisko ${ }^{8}$.

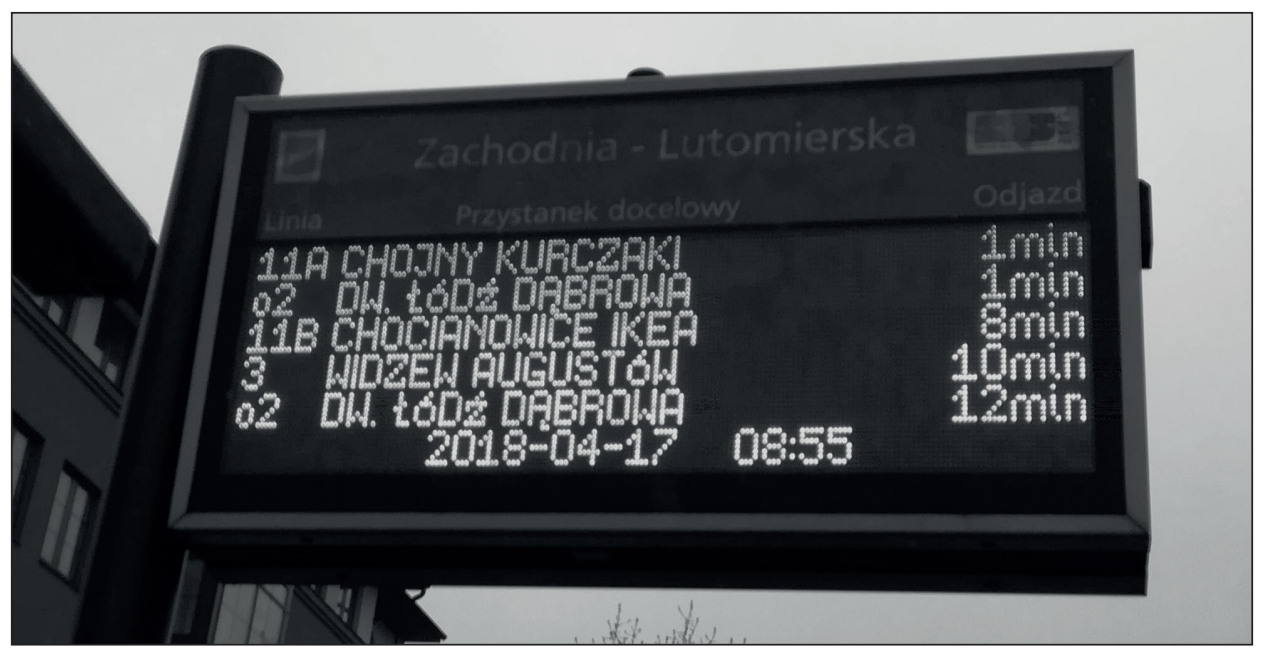

Rysunek 8. Tablica informacji pasażerskiej na przystanku w Lodzi

Źródło: fot. ze zbiorów autora.

W Lokalnym Transporcie Zbiorowym w Łodzi tablice te działają na 191 przystankach tramwajowych i autobusowych, najwięcej zaś jest ich w miejscach postojowych położonych wzdłuż tras Łódzkiego Tramwaju Regionalnego (ŁTR) oraz Wschód-Zachód (WZ) czy też w obrębie węzłów przesiadkowych, np. dworca Łódź Fabryczna i Piotrkowskiej Centrum. Wśród wspomnianych wyżej komunikatów wyświetlanych na tablicach, zwanych potocznie TIP-ami, najczęściej emitowane są informacje o nagłych zatrzymaniach w ruchu pojazdów komunikacji miejskiej oraz planowanych zmianach tras linii komunikacyjnych lub rozkładów jazdy.

Kluczowym jednak zadaniem tablic informacji pasażerskiej jest nadawanie faktycznych godzin przyjazdów tramwajów i autobusów na określony przystanek. Odbywa się to za pomocą sygnałów przekazywanych do tablic elektronicznych

${ }^{7}$ K. Witkowski, Aspekt logistyki miejskiej w gospodarowaniu infrastruktura transportowa miasta, „Studia Lubuskie” 2007, nr 3, s. 211.

8 J. Szołtysek, Podstawy logistyki miejskiej, Wydawnictwo Akademii Ekonomicznej w Katowicach, Katowice 2009, s. 176-177. 
z odbiorników GPS, jakie są zainstalowane w większości pojazdów komunikacji miejskiej w Łodzi. Sygnał ten informuje, gdzie rzeczywiście znajduje się na trasie dany pojazd, dzięki czemu system jest w stanie przeliczyć, w jakim przypuszczalnym czasie powinien on dojechać do konkretnego przystanku przy zachowaniu średniej prędkości o określonej porze dnia. W wypadku gdy urządzenie GPS jest wyłączone, uszkodzone lub niezamontowane, zwłaszcza w starszych tramwajach i autobusach, przez co system nie ma łączności z wozem na trasie, na tablicy wyświetlana jest planowa godzina jego przyjazdu, podana w rozkładzie jazdy. Nie stanowi to jednak gwarancji, że dany środek transportu w ogóle przyjedzie, ponieważ może to być też jednoznaczne $\mathrm{z}$ jego zjazdem $\mathrm{z}$ trasy, np. w wyniku niespodziewanej awarii.

Należy dodać, że dotychczas tablice informacji pasażerskiej w Łodzi były montowane na najważniejszych węzłach przesiadkowych i przystankach przy okazji większych inwestycji w łódzkiej komunikacji zbiorowej, aczkolwiek coraz częściej montaż podobnych tablic informacyjnych w konkretnych punktach postojowych jest celem realizacji projektów zgłaszanych przez mieszkańców do budżetu obywatelskiego. Szczególnymi grupami beneficjentów takich wyświetlaczy zewnętrznych są też np. osoby niewidome, słabo widzące bądź seniorzy, którzy mają problem z odczytem treści emitowanych na tablicach, ponieważ po wciśnięciu specjalnego przycisku zamieszczonego na słupie TIP-a odtwarzany jest automatyczny komunikat głosowy z informacjami o danym przystanku i godzinach odjazdów kilku najbliższych tramwajów czy autobusów miejskich.

\subsection{Wewnętrzne tablice informacyjne w pojazdach komunikacji miejskiej w Lodzi}

Jeszcze do niedawna pasażerowie Lokalnego Transportu Zbiorowego w Łodzi, którzy w trakcie samej podróży (szczególnie tramwajami) chcieli zapoznać się $\mathrm{z}$ trasą danego połączenia, musieli podchodzić do bocznych tablic informacyjnych, wykonanych z dykty, aby dowiedzieć się, jakie będą następne przystanki lub gdzie najlepiej przesiąść się $\mathrm{w}$ inne linie komunikacyjne, zatrzymujące się w tych samych miejscach postojowych bądź w ich sąsiednich punktach, położonych w obrębie danego węzła czy skrzyżowania. Taka forma przekazywania informacji pasażerskiej wciąż jeszcze jest wykorzystywana w starszych modelach tramwajów, które oczekują na gruntowną modernizację.

Już od kilku lat w miejsce starych, wyklejanych tablic informacyjnych wchodzą zupełnie nowe, elektroniczne monitory informacyjne, które są zbudowane na bazie kolorowej matrycy LCD. Podobnie jak wcześniejsze wersje tablic, urządzenia te są przeznaczone do prezentowania przebiegu trasy określonej linii w postaci tzw. koralików (przypominających wyglądem „choinkę", wspomnianą przy nowych rozkładach jazdy). Dodatkowo na bocznych 


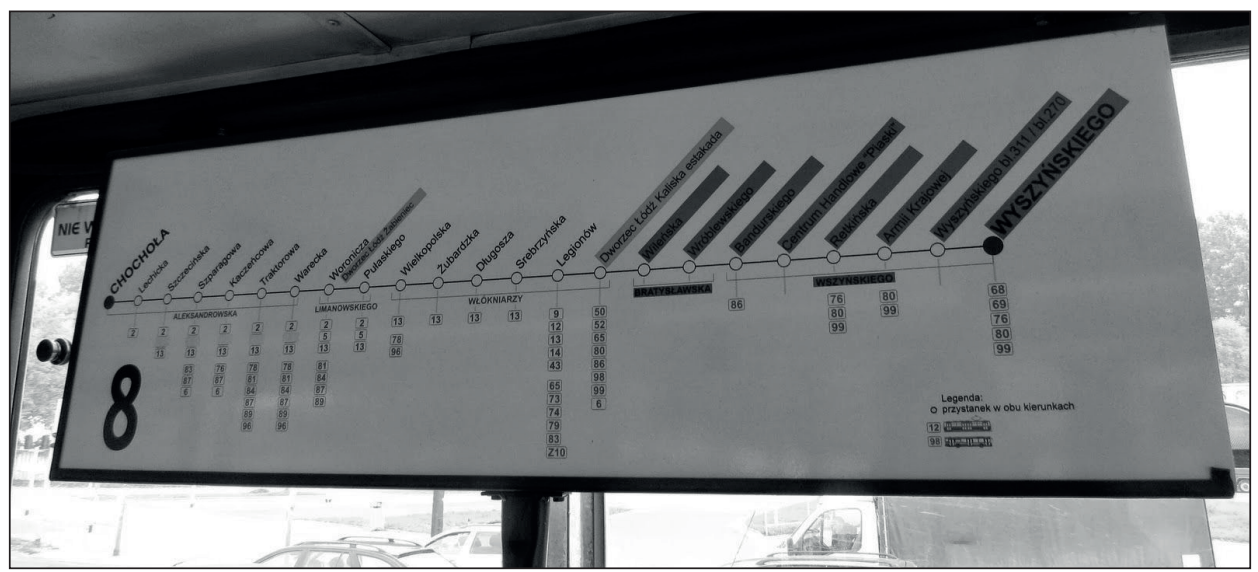

Rysunek 9. Stara boczna tablica informacyjna w tramwaju w Lodzi

Źródło: ZBIORowa KOMunikacja W mieście ŁODZI.

wyświetlaczach podawane są następny i potem obecny przystanek, a także aktualne czasy przejazdu do kolejnych miejsc postojowych. Tego typu tablice montuje się w wagonach, które przeszły kompleksowy remont, oraz w zupełnie nowych tramwajach i autobusach, jakie MPK-Łódź Sp. z o.o. w minionych latach zakupiło i cały czas kupuje do świadczenia usług przewozowych w transporcie publicznym.

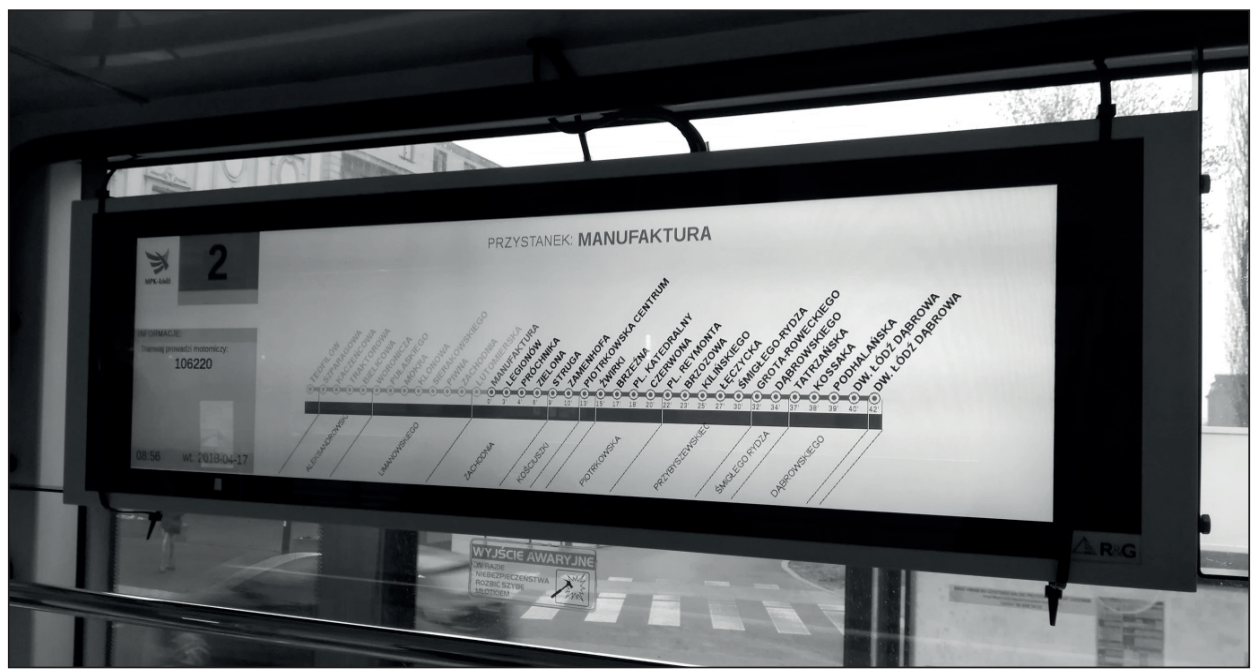

Rysunek 10. Nowa boczna tablica informacyjna w tramwaju w Lodzi

Źródło: fot. ze zbiorów autora. 
Oprócz bocznych tablic elektrycznych z informacją pasażerską w zmodernizowanych lub nowych pojazdach najczęściej pośrodku lub na końcu wagonów instalowane są również jeszcze inne monitory informacyjne z kolorową matrycą LCD. Na tych ekranach, poza informacjami dla pasażerów, operator emituje reklamy oraz publikuje komunikaty specjalne, dotyczące najczęściej zmian w komunikacji zbiorowej. Wśród wewnętrznych tablic informacyjnych w tramwajach i autobusach miejskich są jeszcze tablice diodowe typu XTL, prezentujące informacje m.in. o dacie, godzinie, imieninach, linii, kierunku, następnym przystanku czy przebiegu trasy.

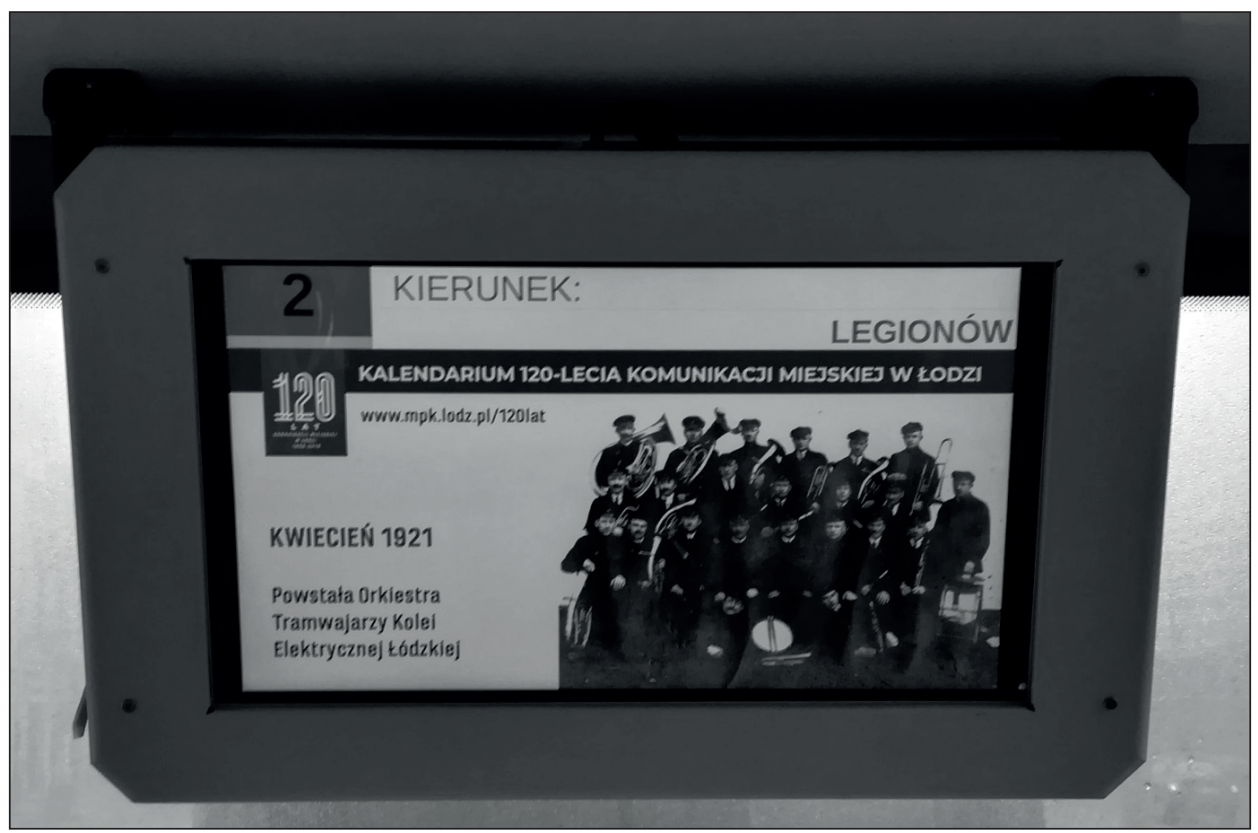

Rysunek 11. Nowa wewnętrzna tablica informacyjna w tramwaju w Lodzi

Źródło: fot. ze zbiorów autora.

\subsection{Nowe zapowiedzi głosowe w pojazdach komunikacji miejskiej w Lodzi}

W ostatnich latach zwłaszcza duże polskie miasta zaczęły wykorzystywać zapowiedzi głosowe w środkach publicznego transportu zbiorowego. To kolejny ważny element informacji pasażerskiej, w który niejednokrotnie zaangażowane są znane w danym ośrodku miejskim bądź charakterystyczne postacie. Idąc tym tropem i biorąc przykład z innych miast, także i w Lodzi postanowiono dokonać zmiany dotychczasowego lektora - Tomasza Boruszczaka. Nastąpiła ona na początku kwietnia 2017 roku wraz z wprowadzeniem nowego układu 
komunikacyjnego, a na nowego lektora w łódzkiej komunikacji miejskiej został wybrany Tomasz Zimoch - pochodzący z Łodzi dziennikarz i komentator sportowy, który w świecie sportu zasłynął m.in. z relacjonowania meczu Widzewa Łódź z Brøndby Kopenhagą w 1996 roku, gdy polski zespół w końcówce zdobył zwycięskiego gola, dającego mu awans do rozgrywek Ligi Mistrzów. Wówczas wypowiedział on pod adresem tureckiego sędziego znane chyba wszystkim słowa: „Panie Turek, niech pan tu kończy to spotkanie”. W oparciu o to zdanie powstała najbardziej rozpoznawalna zapowiedź głosowa Tomasza Zimocha do przystanku Piłsudskiego - Widzew Stadion: „Panie Turek, kończ pan ten mecz. Przystanek Stadion Widzew - legendarne miejsce, legendarny klub, legendarna drużyna".

Współpraca z łódzkim komentatorem nie ograniczyła się jedynie do nagrania zapowiedzi poszczególnych przystanków tramwajowych i autobusowych. Za nazwami większości przystanków zostały dograne dodatkowe zapowiedzi charakterystycznych obiektów znajdujących się w pobliżu tych stacji postojowych, np. dworców, szpitali, urzędów, teatrów, muzeów czy obiektów sportowych. Ponadto głos Tomasza Zimocha w specjalnych komunikatach przypomina podróżnym o skasowaniu biletów, zaleca trzymanie się poręczy, ostrzega przed kieszonkowcami, prosi o ustąpienie miejsc siedzących osobom starszym, zapowiada zmiany w trasach linii komunikacyjnych, wita pasażerów przybywających do Łodzi, życzy miłego dnia w imieniu kierujących pojazdami czy też tworzy odpowiednie zapowiedzi do okolicznościowych świąt.

Pod względem technicznym wszystkie nagrania z komunikatami, składające się na System Informacji Głosowej w łódzkiej komunikacji miejskiej, powinny być plikami nieskompresowanymi o formacie WAVE oraz o częstotliwości próbkowania 44,1 kHz i rozdzielczości 16 bitów.

\subsection{Nowa szata graficzna biletów komunikacji miejskiej w Lodzi}

Zmiany w układzie komunikacyjnym Łodzi wprowadzone w kwietniu 2017 roku były także dobrą okazją do wdrożenia istotnych modyfikacji w systemie opłat za korzystanie z łódzkiego transportu publicznego. Docelowo pojawiły się tańsze bilety okresowe (tzw. migawki) dla seniorów i dzieci oraz rozpoczęły się testy systemu płatności tylko za przejechany dystans (liczbę przystanków). Dużą zmianą była też nowa szata graficzna biletów komunikacji zbiorowej, wybrana w specjalnym głosowaniu mieszkańców, która mogła się spodobać zwłaszcza turystom, z roku na rok coraz chętniej odwiedzającym Łódź. 


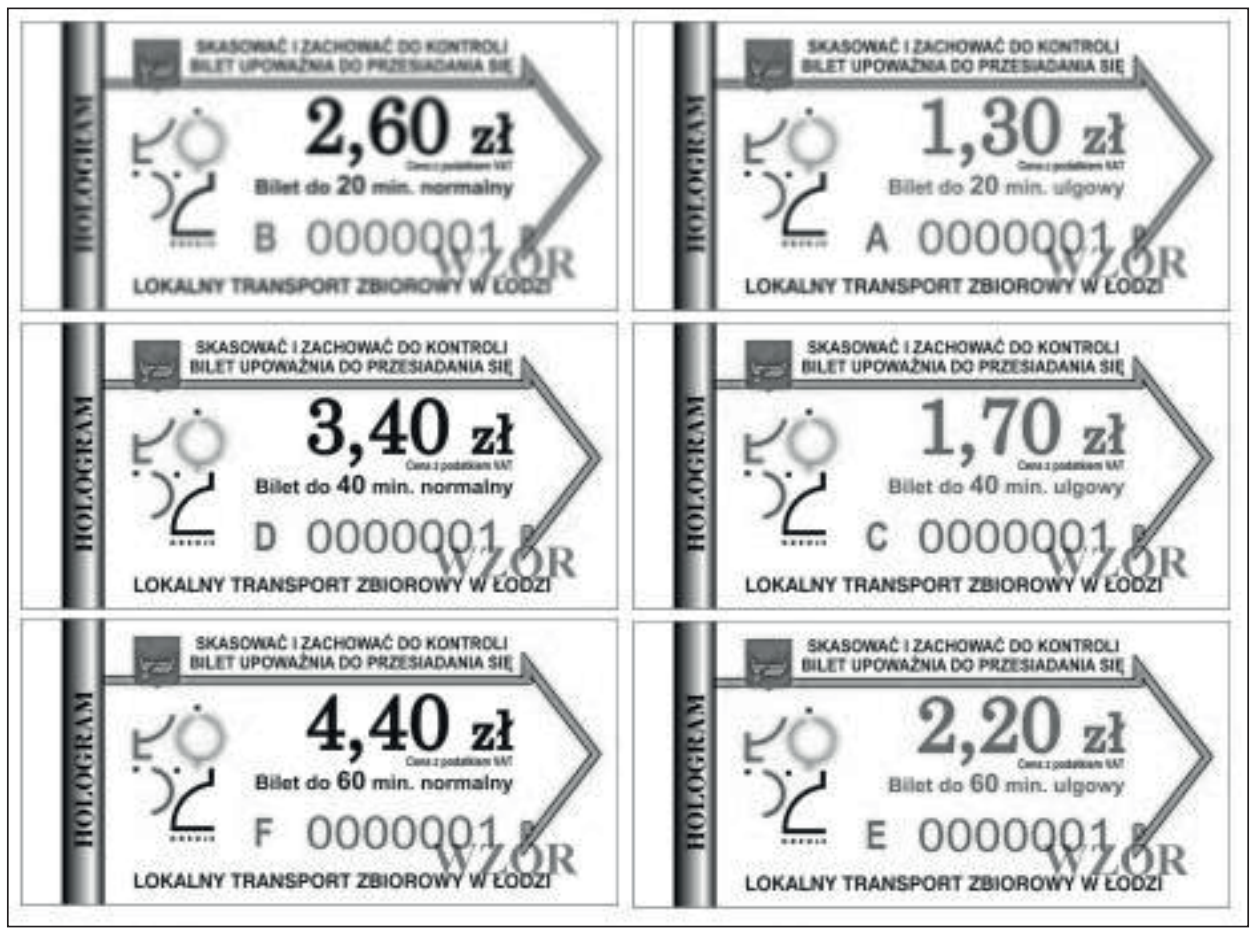

Rysunek 12. Stara szata graficzna biletów komunikacji miejskiej w Lodzi

Źródło: Materiały Miejskiego Przedsiębiorstwa Komunikacyjnego-Łódź Sp. z o.o.

Dotychczasowe bilety czasowe nie różniły się od siebie niczym znaczącym, poza samym nominałem. Jedynymi elementami designu były logotyp i herb miasta. Poza tym stosowany przez lata wzór nie wnosił żadnej większej wartości dodanej dla łódzkich pasażerów. Nowe bilety Lokalnego Transportu Zbiorowego w Łodzi są zdecydowanie bardziej kolorowe, a każda grupa biletów czasowych ma swoją określoną barwę - niebieską (bilety do 20 minut), różową (bilety do 40 minut) lub żółtą (bilety do 60 minut). Zdobią je symbole graficzne charakterystycznych dla miasta obiektów i miejsc, tj. Centrum Nauki i Techniki EC1, placu Wolności, Manufaktury, Przystanku Centrum, woonerfu 6 Sierpnia oraz dworca Łódź Fabryczna wraz z podstawowymi informacjami o tych punktach na odwrocie poszczególnych biletów. Wizualnemu odświeżeniu uległa również migawka, która jest jednym z najpopularniejszych dokumentów w portfelach łódzkiej społeczności. 


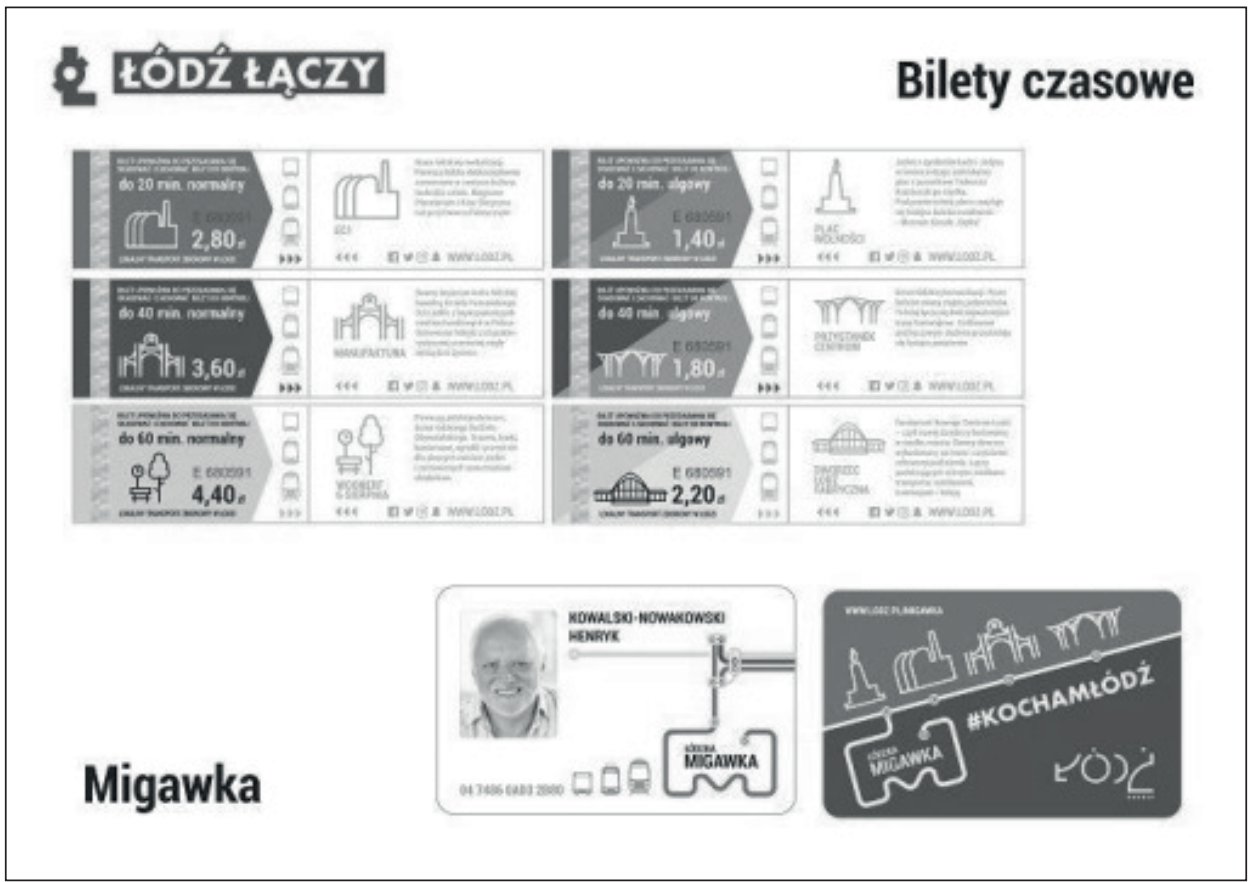

Rysunek 13. Nowa szata graficzna biletów komunikacji miejskiej w Lodzi

Źródło: Materiały Zarządu Dróg i Transportu w Łodzi.

\subsection{Aplikacje mobilne z informacją pasażerską w Lodzi}

W dobie Internetu oraz współczesnych technologii nie można zapominać o możliwościach, jakie zostały stworzone np. dla posiadaczy telefonów komórkowych mających dostęp do sieci. Wśród tysięcy aplikacji mobilnych są też i takie, które stanowią prawdziwą skarbnicę wiedzy dla podróżnych korzystających z komunikacji miejskiej, w tym także na terenie Łodzi. W minionych latach, a nawet w ostatnich miesiącach powstały programy, które powinien posiadać na swoim urządzeniu każdy łódzki pasażer. Wśród tych najbardziej użytecznych aplikacji należy z pewnością wymienić:

- zbiletem.pl - to aplikacja umożliwiająca szybki i bezpieczny zakup biletów przez telefon, za które można płacić kartą, przelewem, blikiem czy PayU; zawiera ona ponadto opcję wygodnej kontroli biletów w smartfonie czy też przypomina o ich ważności,

- myBus - stanowi część Systemu Informacji Pasażerskiej, wchodzącego w skład oprogramowania MUNICOM.premium; poza tradycyjnym rozkładem jazdy w postaci tabliczki przystankowej największą zaletą tej aplikacji jest wyświetlanie najbliższych odjazdów poszczególnych linii 
komunikacyjnych (w tej samej formie co na tablicach informacji pasażerskiej), dzięki danym uzyskanym ze śledzenia tramwajów i autobusów przez system GPS, które pozwalają określić dokładniejszą godzinę pojawienia się pojazdu na przystanku przy jednoczesnym uwzględnieniu aktualnych opóźnień lub przyspieszeń kursu,

- Watch Line Lodz - ma wbudowaną dokładnie taką samą opcję co myBus, jednak w odróżnieniu od poprzedniej propozycji ta aplikacja jest dodatkowo wzbogacona o: wizualizację nowych tras linii komunikacyjnych, powiadomienia o bieżących utrudnieniach w ruchu komunikacji miejskiej na obszarze aglomeracji łódzkiej, integrację z migawką (pozwala na sprawdzenie jej ważności) i Łódzkim Rowerem Publicznym (pokazuje liczbę dostępnych rowerów na określonych stacjach); warto zaznaczyć, że program ten działa w oparciu o stronę Inteligentnych Systemów Transportowych ITS Łódź, która jest dostępna pod adresem: http://rozklady. lodz.pl.

Na uwagę użytkowników Lokalnego Transportu Zbiorowego w Lodzi zasługują również inne aplikacje mobilne, np.: Jakdojade (aplikacja z rozkładami jazdy, wyszukiwarką połączeń i nawigacją GPS), mobileMPK (aplikacja z rozkładami jazdy) czy Przystanek (aplikacja z mapą i zaznaczonymi aktualnymi utrudnieniami w ruchu tramwajów i autobusów w Łodzi).

\section{Metodyka badań}

Liczne starania podmiotów odpowiedzialnych za komunikację miejską w Łodzi, aby informację pasażerską w jak największym stopniu dostosować do potrzeb i oczekiwań podróżnych, poddano także ocenie samych łodzian. W tym celu MPK-Łódź Sp. z o.o. od 31 października do 17 listopada 2017 roku prowadziło ankietę (zwłaszcza drogą elektroniczną) na temat wybranych zmian.

W badaniu wzięło udział aż 3301 respondentów, z czego $66 \%$ badanych miało 15-35 lat, 25\% - od 36 do 55 lat, a pozostałe 9\% powyżej 65 lat. Zdecydowanie największy odsetek (67\%) stanowiły osoby, które codziennie korzystają z usług przewozowych transportu zbiorowego, a zatem przypuszczalnie najczęściej mają kontakt ze środkami informacji pasażerskiej. 


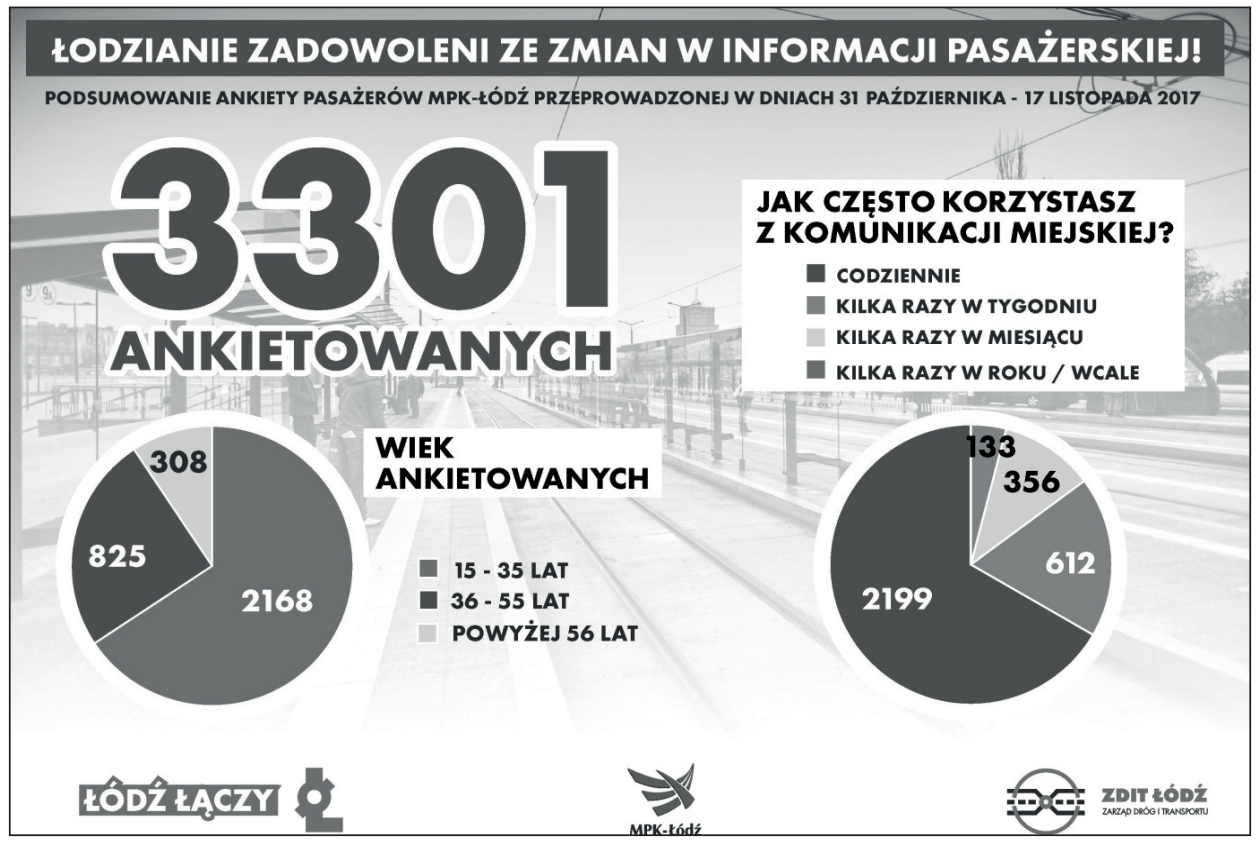

Rysunek 14. Wyniki ankiety na temat informacji pasażerskiej w Lodzi - cz. 1

Źródło: Materiały Miejskiego Przedsiębiorstwa Komunikacyjnego-Łódź Sp. z o.o.

\section{Wyniki badań}

Uzyskane w ankiecie łódzkiego operatora rezultaty potwierdzają, że wprowadzone zmiany w zakresie informacji pasażerskiej w Łodzi spotkały się z przychylnością i akceptacją znacznej części lokalnej ludności. W kwestii wyglądu rozkładów jazdy na przystankach respondenci mieli wskazać, który z kilku różnych szablonów (zaczerpniętych też z innych miast) jest dla nich najbardziej czytelny i przejrzysty. Spośród pięciu propozycji niemal połowę głosów $(47 \%)$ otrzymała wersja łódzkiego, nowego, poprawionego rozkładu, którego szata graficzna została tutaj przybliżona. Z kolei $27 \%$ osób opowiedziało się za starą wersją rozkładu, jaka obowiązywała przez lata aż do kwietnia ubiegłego roku.

Dokładnie taka sama liczba ankietowanych (47\%) zadeklarowała, że wygląd wiat przystankowych wraz z nowymi, udoskonalonymi elementami informacji pasażerskiej (tablicami czołowymi, schematami tramwajowo-autobusowymi czy rozkładami jazdy) bardzo się poprawił. Odmienne stanowisko wyraziło tylko $17 \%$ odpowiadających, natomiast pozostałe $36 \%$ osób nie miało zdania w tej sprawie. 


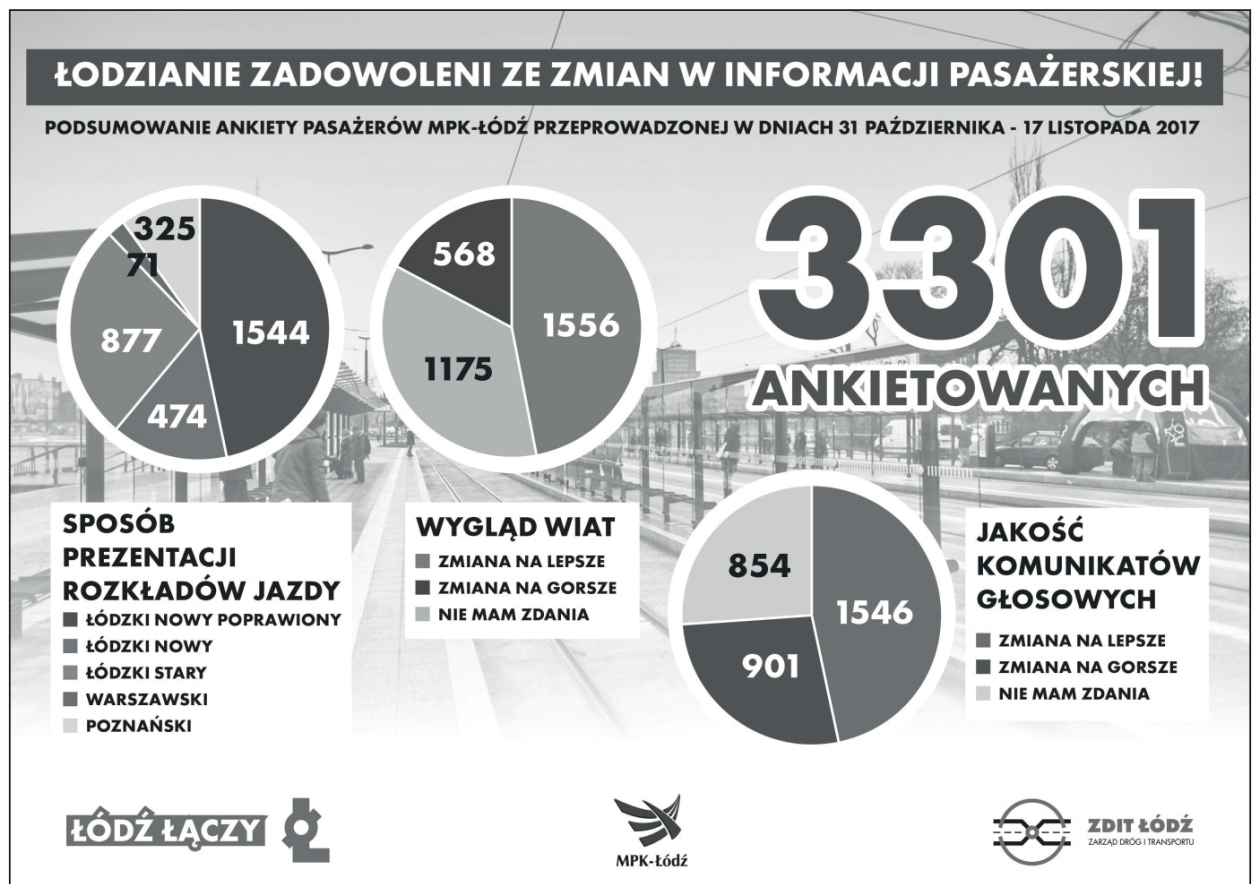

Rysunek 15. Wyniki ankiety na temat informacji pasażerskiej w Lodzi - cz. 2

Źródło: Materiały Miejskiego Przedsiębiorstwa Komunikacyjnego-Łódź Sp. z o.o.

Trzecia część badania dotyczyła jakości zapowiedzi głosowych utworzonych we współpracy z Tomaszem Zimochem. Po raz kolejny taki sam odsetek ankietowanych $-47 \%$ - uznał, że były to zmiany na lepsze. Nie spodobały się one za to $27 \%$ respondentów. Niemal tyle samo ankietowanych (26\%) nie określiło, czy akceptuje komunikaty w pojazdach transportu zbiorowego nagrywane przez nowego lektora.

\section{Podsumowanie i wnioski}

W niniejszym artykule przedstawiono funkcjonowanie dawnej i teraźniejszej informacji pasażerskiej w komunikacji zbiorowej w Łodzi. Podstawowym celem stosowania różnorodnych środków informacyjnych dla pasażerów jest ułatwienie podróży po mieście, co może mieć wpływ na zwiększenie zainteresowania tym sposobem przemieszczania się wśród mieszkańców i zachęcenie ich do przesiadania się $\mathrm{w}$ tramwaje lub autobusy miejskie. W rezultacie następuje zmiana zachowań komunikacyjnych lokalnej społeczności, a przez to odczuwalne jest dla wszystkich zmniejszenie negatywnych efektów kongestii transportowej, co też 
znajduje się pośród najważniejszych założeń koncepcji transportu zrównoważonego, będącej elementem ekonomii zrównoważonego rozwoju.

$\mathrm{W}$ ostatnich latach, a także miesiącach w Lodzi wprowadzono wiele istotnych zmian w zakresie udoskonalania informacji pasażerskiej dla podróżujących Lokalnym Transportem Zbiorowym. Najwięcej z nich dokonano przy okazji wprowadzania nowego układu komunikacyjnego w aglomeracji łódzkiej w kwietniu 2017 roku, a najbardziej zauważalne zmiany dotyczyły przystanków tramwajowych i autobusowych czy samych pojazdach komunikacji miejskiej.

W odniesieniu do postawionego we wstępie artykułu problemu badawczego należy zatem stwierdzić, że ciągły rozwój i unowocześnianie środków informacji pasażerskiej przynoszą zamierzone efekty. W wypadku Łodzi podobne działania spotkały się z uznaniem podróżujących, których duży odsetek pozytywnie wypowiedział się na ten temat $\mathrm{w}$ ankiecie, jaką jesienią 2017 roku zorganizowało MPK-Łódź Sp. z o.o. Należy więc oczekiwać, że dalsza poprawa łódzkiego systemu informacji pasażerskiej będzie w najbliższej przyszłości wpływać dodatnio na liczbę użytkowników publicznego transportu zbiorowego w Łodzi.

\section{Bibliografia}

Brzeziński A., Rezwow M., Zrównoważony transport - ekologiczne rozwiąania transportowe, http:// www.transeko.pl/publik/Ekorozwoj_czesc\%20transportowa\%20A\%20Z.pdf [dostęp: 15.04.2018].

Cichosz M., Innowacje w logistyce miejskiej-zrównoważony transport publiczny, „Prace Naukowe Uniwersytetu Ekonomicznego we Wrocławiu", nr 383, Wydawnictwo Uniwersytetu Ekonomicznego we Wrocławiu, Wrocław 2015.

OECD, Toward sustainable transportation, The Vancouver Conference 24-27 March, Vancouver 1996.

Szołtysek J., Podstawy logistyki miejskiej, Wydawnictwo Akademii Ekonomicznej w Katowicach, Katowice 2009.

Witkowski K., Aspekt logistyki miejskiej w gospodarowaniu infrastruktura transportowa miasta, „Studia Lubuskie” 2007, nr 3.

Wydro K.B., Telematyka - znaczenia $i$ definicje terminu, ,Telekomunikacja i Techniki Informacyjne" 2005, nr 1-2.

Zarządzanie komunikacją miejska, red. O. Wyszomirski, Gdańska Fundacja Kształcenia Menedżerów, Gdańsk 1999.

\section{Streszczenie}

W niniejszym artykule przedstawiono wpływ informacji pasażerskiej na decyzje transportowe mieszkańców oraz politykę transportową miast. Ponadto autor wskazał rolę informacji pasażerskiej w koncepcji transportu zrównoważonego, a tym samym w ekonomii zrównoważonego rozwoju. Następnie opisał zmiany, 
jakie wprowadzono w systemie informacji pasażerskiej w Łodzi, podając za przykład postępy w zakresie m.in. schematów komunikacyjnych, tablic informacji pasażerskiej, zapowiedzi głosowych czy aplikacji mobilnych. Na koniec autor zaprezentował wyniki badań MPK-Łódź Sp. z o.o. na temat wprowadzonych zmian w systemie informacji pasażerskiej w Łodzi.

Słowa kluczowe: informacja pasażerska, system informacji pasażerskiej, komunikacja miejska, publiczny transport zbiorowy, tablice informacji pasażerskiej, schematy komunikacyjne, zapowiedzi głosowe, aplikacje mobilne

Numer klasyfikacji JEL: O18, O32, R41 